IZA DP No. 9620

Are Japanese Men of Pensionable Age Underemployed or Overemployed?

Emiko Usui

Satoshi Shimizutani

Takashi Oshio

December 2015 


\title{
Are Japanese Men of Pensionable Age Underemployed or Overemployed?
}

\author{
Emiko Usui \\ Hitotsubashi University and IZA \\ Satoshi Shimizutani \\ Institute for International Policy Studies
}

Takashi Oshio

Hitotsubashi University

Discussion Paper No. 9620

December 2015

\author{
IZA \\ P.O. Box 7240 \\ 53072 Bonn \\ Germany \\ Phone: +49-228-3894-0 \\ Fax: +49-228-3894-180 \\ E-mail: iza@iza.org
}

\begin{abstract}
Any opinions expressed here are those of the author(s) and not those of IZA. Research published in this series may include views on policy, but the institute itself takes no institutional policy positions. The IZA research network is committed to the IZA Guiding Principles of Research Integrity.

The Institute for the Study of Labor (IZA) in Bonn is a local and virtual international research center and a place of communication between science, politics and business. IZA is an independent nonprofit organization supported by Deutsche Post Foundation. The center is associated with the University of Bonn and offers a stimulating research environment through its international network, workshops and conferences, data service, project support, research visits and doctoral program. IZA engages in (i) original and internationally competitive research in all fields of labor economics, (ii) development of policy concepts, and (iii) dissemination of research results and concepts to the interested public.
\end{abstract}

IZA Discussion Papers often represent preliminary work and are circulated to encourage discussion. Citation of such a paper should account for its provisional character. A revised version may be available directly from the author. 
IZA Discussion Paper No. 9620

December 2015

\title{
ABSTRACT
}

\section{Are Japanese Men of Pensionable Age Underemployed or Overemployed?*}

\begin{abstract}
We investigate how Japanese men aged 60-74 adjust their workforce attachment after beginning to receive a public pension. Men who were employees at age 54 gradually move to part-time work or retire after beginning to receive pension benefits; those who continue working are more likely to be underemployed. Men self-employed at age 54 , however, neither retire nor reduce their working hours even after beginning to receive pension benefits; these men are more likely to be overemployed. In contrast, U.S. men retire or move to part-time when they first claim Social Security; those who continue working as employees after Social Security starts are unlikely to be either over- or underemployed. Therefore, unlike U.S. men, Japanese men are not choosing the optimal pensionable age and labor hours to maximize their intertemporal utility.
\end{abstract}

JEL Classification: J26, I10, H55

Keywords: Japanese Study on Aging and Retirement (JSTAR), pension benefits, Health and Retirement Study (HRS), work hours, hours constraints, Japan

Corresponding author:

Emiko Usui

Institute of Economic Research

Hitotsubashi University

Kunitachi, 186-8603 Tokyo

Japan

E-mail: usui@ier.hit-u.ac.jp

\footnotetext{
* For their helpful comments and suggestions, we would like to thank an anonymous referee, as well as Mitsuhiro Fukao, Michael Hurd, Hidehiko Ichimura, Italo López García, Tsunao Okumura, Tadashi Sakai, Kimiko Terai, the participants in RAND International Comparisons Workshop, RIETI/JER Workshop, Trans-Pacific Labor Seminar, annual conference of Japan Health Economics Association, and seminar participants in Keio University. This research is supported by JSPS grant $15 \mathrm{H} 03343$ and $15 \mathrm{H} 05692$.
} 


\section{Introduction}

Most Japanese men, approximately 90 percent, have high labor-force attachment until they reach age 60, according to the Population Census of Japan (2010). They gradually move from the labor force to retirement throughout their $60 \mathrm{~s}$, and approximately 75 percent are out of the labor force at age 75. Recently, Usui, Shimizutani, and Oshio (2015) found substantial work capacity among men over age 60: 16.0 percent, 40.2 percent, and 56.0 percent of men in the age groups of 60-64, 65-69, and 70-74 years, respectively, could potentially move from retirement to work, assuming that the relationship between their health and their employment status remains unchanged from that which held in their 50s. ${ }^{1}$ These results suggest that changes in men's work status from age 60 to 74, as they move from work to retirement, are not fully attributable to deteriorating health conditions, partly because their health declines slowly and does not deteriorate significantly throughout their 60 s.

In this paper, we examine why men from ages 60 to 74 move from full-time to part-time status or retirement even when their health status does not necessarily require them to do so. Because working arrangements in Japan may create substantial differences between salaried workers and the self-employed, we divide the sample into two groups: those who had salaried jobs at age 54 and those who were self-employed at age 54. Specifically, those men who have salaried jobs in their 50s tend to work in jobs subject to mandatory retirement, and therefore, they often leave their jobs because of mandatory retirement and find new jobs if they wish to continue working (Clark and Ogawa, 1997; Shimizutani and Oshio, 2010). Furthermore, this group of workers is often covered by Employees' Pension Insurance (EPI), whose benefits consist of both flat-rate and earnings-related components. Meanwhile, those who are self-employed in their 50s are not

\footnotetext{
${ }^{1}$ Usui, Shimizutani, and Oshio (2015) estimate the elderly's work capacity (the ability to work based on their health) using the method of Cutler, Meara, and Richands-Shubik (2012). Usui, Shimizutani, and Oshio (2015) first estimate the association between health and employment among those aged from 51 to 54. Then, based on the estimated associations, they project employment among those over age 55 to assess how much the observed decline in labor force participation can be explained by deteriorating health.
} 
subject to mandatory retirement and are not obliged to change employers during their $60 \mathrm{~s}$. In terms of pensions, most of these men are eligible to receive National Pension Insurance (NPI) benefits, which consist only of the flat-rate component and are thus less generous than EPI benefits.

We use data from the Japanese Study of Aging and Retirement (JSTAR), which covers a wide range of information about the economic, social, and health status of middle-aged and older adults. We also compare our results with U.S. data using the Health and Retirement Study (HRS), which provides data comparable with Japanese data, along with information on the two countries' very different systems regarding work opportunities for those over age 60 and their social security arrangements.

Using the JSTAR, we find substantial differences in work and retirement behaviors between Japanese men who had salaried jobs at age 54 and those who were self-employed at age 54 . Among the men who were employees at age 54, those who expect to receive greater public pension benefits in the future or those who are already doing so are more likely to retire or work part-time than to work full-time. We also find that these men gradually move from full-time employment to part-time employment or retirement after they begin to receive pension benefits. For those who work after they begin to receive pension benefits, the hours worked per week gradually decline. Meanwhile, among the men who were self-employed at age 54, their decisions to move from fulltime employment to part-time employment or retirement are more likely to be associated with their deteriorating health than with the amount of their (expected) public pension benefits. Furthermore, there is no significant change in their employment status or their working hourshours worked per week and weeks worked per year-before and after they begin to receive pension benefits. Therefore, these workers remain in the labor force even after they begin to receive pension benefits.

In contrast, our analysis using the HRS shows that just after beginning to receive Social Security, U.S. men — especially white men — exhibit abrupt changes from full-time employment to part-time employment or retirement and, as a result, abrupt changes in hours worked. Therefore, 
for U.S. men, the decision to receive Social Security coincides with their decision to retire or reduce their working hours. This finding is in sharp contrast to (1) Japanese men who had salaried jobs at age 54, whose working hours after they began to receive public pension gradually declined, and (2) Japanese men who were self-employed at age 54, who did not change their work status or working hours even after they began to receive pension benefits.

According to the models of the intertemporal substitution of the labor supply, rational, forward-looking individuals choose their labor hours for the present and future and choose their pensionable ages to maximize their intertemporal lifetime utility. Because individuals optimally choose hours worked, under this model, individuals are not likely to report either over- or underemployment after they begin to receive pension benefits compared with their reporting before they began receiving pension benefits. ${ }^{2}$ We find that among Japanese men who had salaried jobs at age 54 , those who work after they begin to receive pension benefits are more likely to report underemployment. In contrast, among Japanese men who were self-employed at age 54, those who work after they begin to receive pension benefits are more likely to report overemployment. These results are different from those from the HRS, which indicate that U.S. men who work as employees are less likely to report either overemployment or underemployment after they begin to receive Social Security. Therefore, whereas U.S. men adjust their employment status and working hours and are more satisfied with their hours worked when they begin to claim Social Security, Japanese men appear to have difficulty choosing optimal pensionable ages and labor hours to maximize their lifetime utility.

\section{Overview of the Public Pension Scheme in Japan}

We begin by providing an overview of the public pension scheme in Japan. The public oldage pension scheme in Japan is composed of three plans: (1) National Pension Insurance (NPI,

\footnotetext{
${ }^{2}$ However, empirical studies have observed that many employees are not perfectly matched to jobs with their desired working hours, and that those who report dissatisfaction with their hours change employers to work in jobs that are more in line with their preferred hours (Altonji and Paxson, 1988; 1992; Kahn and Lang, 1991, 1995; Lang and Kahn, 2001).
} 
Kokumin Nenkin) for self-employed workers and non-employed people; (2) Employees' Pension Insurance (EPI, Kosei Nenkin) for those employed by private companies that regularly employ 5 workers or more; and (3) Mutual Aid Insurance (MAI, Kyosai Nenkin) for those employed in the public sector and private schools. In 2007, the NPI, EPI, and MAI covered 45.5 percent, 48.0 percent, and 6.5 percent, respectively, of the population insured by public pension programs (Oshio, Oishi, and Shimizutani, 2011). Because the MAI has almost the same benefit scheme as the EPI, the MAI and the EPI are combined in the JSTAR questionnaire. The NPI consists only of a flat-rate benefit (the so-called Old-Age Basic Pension, Rorei Kiso Nenkin), whereas the EPI consists of an "earnings-related pension" in addition to the flat-rate "Old-Age Basic Pension" provided by the NPI system.

The normal pensionable age for the NPI is 65 . NPI beneficiaries can start to receive NPI benefits either earlier (Kuriage) or later (Kurisage) than the normal pensionable ages, with the pension benefits adjusted actuarially. In the JSTAR sample, among men aged 60 to 64 who are eligible to receive NPI benefits, 40.6 percent are already receiving them. ${ }^{3}$ However, it is rare for a man to begin to claim benefits later than the normal pensionable age.

For EPI beneficiaries, the pensionable ages for flat-rate and earnings-related benefits, both of which were set in 1973 at age 60 for men, have been scheduled to be raised to age 65 . In the first stage, the pensionable age for flat-rate benefits was raised one year every three years from 2001 to 2013, when it reached age 65. In the second stage, the pensionable age for earnings-related benefits is planned to rise by one year every three years from 2013 to 2025 , when it will reach age $65 .^{4}$

\footnotetext{
3 The statistics from the Ministry of Health, Labour and Welfare (2007) indicate that more than 40 percent of NPI beneficiaries begin to claim benefits between ages 60 and 64 .

${ }^{4}$ To provide stable employment for those in their early 60 s who would no longer be eligible for the flatrate EPI because the pensionable age had been raised, the government passed the Law Concerning the Stabilization of Employment of Older Persons in 2004. This law requires companies to extend employment up to the pensionable age; thus, it obligates companies to gradually raise the mandatory retirement age or to keep employing workers from 60 to 65 by introducing a continued employment system or to abolish mandatory retirement altogether.
} 
Similar to NPI beneficiaries, EPI beneficiaries can start to claim EPI benefits either earlier or later than the normal pensionable age. In the JSTAR sample, among men aged from 60 to 64 who are eligible to receive EPI benefits, 72.0 percent are already receiving them. ${ }^{5}$ If EPI recipients keep working after reaching the pensionable age, an earnings test for pension benefits is used to reduce their pension benefits if earnings exceed specified amounts (Zaishoku Rorei Nenkin). ${ }^{6}$

The Old-Age, Survivors, and Disability Insurance (OASDI), which corresponds to Social Security benefits in the United States, has similar programs for earlier/later claiming, but the earnings test for Social Security beneficiaries who reached the full retirement age was eliminated in 2000 .

\section{Data}

The data used in this study are from the JSTAR, which is designed and conducted jointly by the Research Institute of Economy, Trade, and Industry (RIETI), Hitotsubashi University, and the University of Tokyo. The JSTAR is Japan's first globally comparable panel data survey of the elderly. Its design is similar to that of the HRS in the U.S., the Survey of Health, Ageing and Retirement in Europe (SHARE), and the English Longitudinal Study of Ageing (ELSA). The JSTAR covers a wide range of information, including the economic, social, and health conditions

\footnotetext{
${ }^{5}$ More than 60 percent of EPI beneficiaries start to claim pension benefits between ages 60 and 64 (Ministry of Health, Labour and Welfare, 2007). Because government statistics are not available for the proportion of MAI beneficiaries who begin to claim MAI benefits, we cannot make a comparison between the JSTAR sample and government statistics.

${ }^{6}$ In the JSTAR sample, among those who work while receiving a public pension, 34.4 percent report that their earnings are above the exemption amount, such that their pension benefits are reduced; 48.2 percent report that their earnings are below the exemption amount, such that their pension benefits are not affected; and 16.5 percent report that they do not know whether their pension benefits are affected. The 48.2 percent whose earnings are below the exemption amount consist of a mix of two groups: (1) those who choose their labor hours optimally, and (2) those who are "underemployed" (because they would like to work more but cannot do so under the earnings test for public pensions). Among the 48.2 percent, there appears to be no bunching around the annual labor income of 3,360,000 yen (the threshold at which benefits begin to be partially reduced); therefore, those who are "underemployed" may not constitute a significant portion of this group.
} 
of middle-aged and older adults. A detailed description of the survey's design and sample methodology can be found in Ichimura, Hashimoto, and Shimizutani (2009).

The individuals in the baseline JSTAR sample were between ages 50 and 75 . The baseline sample (hereafter referred to as "Baseline Sample 1") was surveyed in 2007 from among people who lived in the following five municipalities in Japan: (1) Takikawa City in Hokkaido Prefecture, (2) Sendai City in Miyagi Prefecture, (3) Adachi Ward in the Tokyo metropolis, (4) Kanazawa City in Ishikawa Prefecture, and (5) Shirakawa Town in Gifu Prefecture. The JSTAR expanded the sample (hereafter, "Baseline Sample 2") by adding those who lived in Naha City in Okinawa Prefecture in 2008 and those who lived in Tosu City in Saga Prefecture in 2009. In 2011, those who lived in Chofu City in the Tokyo metropolis, Tondabayashi City in Osaka Prefecture, and Hiroshima City in Hiroshima Prefecture were also added to the JSTAR (yielding "Baseline Sample 3 "). ${ }^{7}$ The response rate in the baseline sample was near 60 percent, and the sample comprised a total of 7,723 participants. The second wave of data collection for Baseline Sample 1 was conducted in 2009, and that for Baseline Sample 2 was conducted in 2011. The third wave of data collection for Baseline Sample 1 was also conducted in 2011.

In the analysis, we restrict the data to male respondents from ages 60 to 74 . We separate the respondents by the jobs they held at age 54 into (1) those who had salaried jobs and (2) those who were self-employed. As for the respondents' employment history, the JSTAR asks respondents about their jobs at age 54, under the assumption that it is a reasonable indicator of respondents' careers before their mid-50s. ${ }^{8}$ In Japan, those who have salaried jobs in their 50s tend to be subject

\footnotetext{
${ }^{7}$ The JSTAR is not a probabilistic national sampling, but within the ten cities, the researchers selected a probabilistic sample for each site.

${ }^{8}$ There may be a concern that men around the age of 54 may choose to move from salaried jobs to selfemployment, hoping to secure a job that they can continue to hold even after mandatory retirement; in such a case, those who expect to have greater labor force attachment after mandatory retirement are more likely to choose to be self-employed at age 54. However, the number of those who move to self-employment during their $50 \mathrm{~s}$ is smaller than those who do so in their early $60 \mathrm{~s}$. In particular, among those who had salaried jobs during their 50s, only 2.6 percent have moved to self-employment two years later, while among those who had salaried jobs between the ages of 60 and 64, 5.1 percent have moved to selfemployment two years later. Moreover, the main reason why some people in their 50s move from salaried
} 
to mandatory retirement arrangements. After mandatory retirement-which often comes between the ages of 60 and $65-$ workers need to find new employment if they want to continue working. Meanwhile, those who are self-employed are not under mandatory retirement arrangements and are therefore not obliged to change employers during their $60 \mathrm{~s}$.

In the JSTAR sample used in this paper, 2,513 men held salaried jobs at age 54, and 885 men were self-employed at age 54; hence, approximately one-fourth of the men in the sample were self-employed at age 54 .

For comparison, we use the HRS, a biennial survey of the U.S. population over age 50 . The original HRS cohort was first interviewed in 1992 for a nationally representative sample of individuals born between 1931 and 1941. We use cohorts that entered the HRS in 1998 and 2004, and we use data from the first to the eleventh waves, through 2012. Similar to our procedure for the JSTAR, for the HRS we restrict the sample to men between ages 60 and 74. In the HRS, the questions on hours constraints (which we use to construct indicators for overemployment and underemployment) were not presented to those who were self-employed at the time of the interview. Therefore, for the analysis of work hours and hours constraints using the HRS sample, self-employed individuals are excluded. Ultimately, using the U.S. data, we make a rough comparison between U.S. men and Japanese men who had salaried jobs at age 54 in the JSTAR sample. In the HRS sample, there are 8,214 white men and 1,507 black men. Appendix Table 1 provides the characteristics of the JSTAR and HRS samples.

\section{Descriptive statistics}

Figure 1 displays the distribution of employment status by age for Japanese men and U.S. men. For Japanese men who had salaried jobs at age 54, Panel A uses the first wave of the baseline

\footnotetext{
jobs to self-employment may be entrepreneurial motivations: aiming for higher income and/or as a response to dismissal from a salaried job. In their early 50s, salaried workers in Japan tend to earn the highest salaries they will earn in their lifetimes, so they are less likely to voluntarily leave their current employment.
} 
samples to separately plot the proportions of (i) men between ages 55 and 74 who work full-time, (ii) those who work part-time, and (iii) those who are retired. Panel B then plots the same three proportions for those Japanese men who were self-employed at age 54 (also using the first wave of the baseline samples). Panel C plots the same three proportions for the U.S. men (using the first wave of the HRS sample). "Full-time" refers to 35 or more hours of work per week, whereas "part-time" refers to fewer than 35 hours of work per week.

For Japanese men who had salaried jobs at age 54, approximately 90 percent of them continue to work full-time until the age of 59 . Then, they gradually shift to part-time work or retirement. ${ }^{9}$ During their early 70s, the proportion of those who work part-time declines, and that of those who retire increases. At age 74, 86.3 percent of men have retired, and only 7.5 percent and 6.3 percent work part- and full-time, respectively.

Meanwhile, for those who were self-employed at age 54, the shift from full-time employment to part-time employment or retirement is more gradual. The proportion of those who work fulltime gradually declines from age 55 to 74 , and there is not a distinct change in the pace of decline beginning at age 60 , as was observed for those who had salaried jobs at age 54 . Additionally, there is no decline in the proportion of those who work part-time from their late 60 s to their early $70 \mathrm{~s}$, as was observed for those who had salaried jobs at age 54. At age 74, 35.3 percent still work fulltime, 20.6 percent work part-time, and 44.1 percent are retired. The proportion of these men who are retired is approximately 40 percent lower than that for those who had salaried jobs at age 54 .

Therefore, there is a distinct difference in work and retirement behaviors between those who had salaried jobs at age 54 and those who were self-employed at age 54 . The self-employment rate for male workers in 2010 was 12.6 percent in Japan, which is higher than the 7.5 percent in the U.S. (OECD, 2014), and the well-being of these self-employed men is as important as that of

\footnotetext{
${ }^{9}$ This is in accordance with Shimizutani and Oshio (2010), who find that a substantial proportion of the Japanese elderly move to part-time jobs after they retire from their primary, full-time jobs rather than completely leaving the labor force, based on the data from the Survey on Employment of the Elderly.
} 
the employed. Because of the differences between these two groups in terms of their employment opportunities and public pension arrangements, as described in detail in Section 2, it is important to distinguish the two groups when we think about the work and retirement behaviors of the Japanese elderly.

\section{Determinants of employment status for Japanese men between ages 60 and 74}

We begin by estimating a multinomial logit model of the choice to work full-time, work parttime, or retire, using all waves of the panel data of the JSTAR. We use this model to examine which demographic, health, and pension-related variables are associated with employment status among Japanese men between the ages of 60 and 74. The regressions include demographic characteristics (e.g., age, education, and marital status), various health measures, ${ }^{10}$ and individuals' expected or actual annual pension benefits. The variable for expected or actual annual pension benefits is the actual amount of annual pension benefits if the respondent is currently receiving a pension, or the expected amount of annual pension benefits if the respondent is not currently receiving but expects to receive in the future. ${ }^{11}$

Table 1 reports the relative risk ratios from the multinomial logit regression for the sample of Japanese men who had salaried jobs at age 54 (left panel) and for those who were self-employed

10 Health variables include: (1) self-assessed health, (2) physical functional limitations, (3) IADL (instrumental activities of daily living) limitations, (4) various types of illness (heart disease, lung disease, stroke, psychiatric disorders, cancer, hypertension, arthritis, and diabetes), (5) CES-D (the Center for Epidemiologic Studies Depression Scale) score, (6) weight, and (7) smoking behaviors. Health conditions have been found to be closely associated with the elderly's decisions about work and retirement (Wise, 2012; McGarry, 2004, 2009).

${ }^{11}$ Because the government has been distributing official notifications of future pension benefits to possible future pensioners since 2009, even those who do not currently receive pension benefits are likely to have better knowledge of their expected amount of annual pension benefits than they would have in the past. We therefore assume here that people have the information needed to correctly expect the amount of annual pension benefits they will receive in the future if they are not currently receiving them. However, using the JSTAR, Okumura and Usui (2014) find that 8.3 percent of those who plan to receive pension benefits in the future do not know the exact amount they will receive. Therefore, the regression in Table 1 includes a dummy for whether an individual reported not knowing the amount of annual pension benefits for which he is eligible. 
at age 54 (right panel). The depending variable is the employment status (part-time employment or retirement) with full-time employment as the reference category.

When one looks at the health variables for those who had salaried jobs at age 54, those who report their health as fair or poor are 1.931 times more likely to be retired than to work full-time, and 0.933 times more likely to work part-time than to work full-time. However, for those who were self-employed at age 54, those who report their health as fair or poor are 2.525 times more likely to be retired than to work full-time, and 3.859 times more likely to work part-time than to work full-time. Therefore, those who were self-employed at age 54 and report their health as fair or poor have a higher likelihood of retiring or of working part-time than working full-time, compared to others who also report their health as fair or poor but who had a salaried job at age 54.

At the same time, for those who were self-employed at age 54, health problems appear to be related to their decision to retire or work part-time. Specifically, those who have arthritis are 3.812 times more likely to work part-time than to work full-time; those who had a stroke are 6.264 times more likely to retire than to work full-time, and 5.653 times more likely to work part-time than to work full-time; and those who have IADL (instrumental activities of daily living) limitations are 5.879 times more likely to retire than to work full-time. ${ }^{12}$

For those who had salaried jobs at age 54, given a 1-million-yen increase in expected or actual annual pension benefits, they are 2.315 times more likely to be retired than to work full-time and 1.804 times more likely to work part-time than to work full-time. That is, these individuals with

\footnotetext{
12 Those who have more than two physical functional limitations are 2.633 times more likely to retire than to work full-time if they had salaried jobs at age 54, and 2.651 times more likely to retire than to work fulltime if they were self-employed at age 54. This means that regardless of their work status at age 54, this group is more likely to retire than to work full time. Note that the physical functional limitations include limitations in performing the following: (1) walking 100 meters, (2) sitting for about 2 hours, (3) getting up from a chair after sitting for long periods, (4) climbing several flights of stairs without resting, (5) climbing one flight of stairs without resting, (6) stooping, kneeling, or crouching, (7) lifting arms above shoulder level, (8) pushing or pulling large objects, (9) lifting or carrying weights over $5 \mathrm{~kg}$, and (10) picking up a 1 yen coin from the table.
} 
higher expected or actual annual pension benefits are more likely to retire or to work part-time than to work full-time. Meanwhile, for those who were self-employed at age 54, the amount of annual pension benefits they receive or expect to receive does not have a statistically significant association with their likelihood of retiring or of working part-time rather than working fulltime..$^{13}$

There is a large difference in the amounts of the actual and expected annual pension benefits between those who held salaried jobs at age 54 and those who were self-employed at age 54 . Specifically, for those who had salaried jobs at age 54, the median expected or actual annual pension benefits are 2 million yen for those who have retired, 1,800,000 yen for those who work part-time, and 720,000 yen for those who work full-time. For those who were self-employed at age 54, the median expected or actual annual pension benefits are 840,000 yen for those who have retired, 720,000 yen for those who work part-time, and 690,000 yen for those who work full-time. Therefore, the amounts of the expected or actual annual pension benefits are much larger for those who had salaried jobs at age 54 than for those who were self-employed at age 54, conditional on current employment status. Furthermore, for those who were self-employed at age 54, the expected or actual annual pension benefit amounts vary much less by current employment status compared with the benefits for those who had salaried jobs at age 54. Because the two groups differ in the amount of public pension benefits they are entitled to receive, their work and retirement behaviors after they begin to receive pension benefits are likely to differ. In the following section, we examine how the two groups differ in the changes in work vs. retirement and hours constraints before and after they begin to receive pension benefits.

\section{Changes in employment status before and after the initial claim for pension benefits}

We estimate a multinomial logit model of the choice to work full-time, to work part-time, or

\footnotetext{
13 Among both those who had salaried jobs at age 54 and those who were self-employed at that age, those who have a higher subjective expected probability of survival until age 85 are less likely to be retired than to be working full-time.
} 
to retire, similar to that shown in Table 1, by replacing the amounts of expected or actual annual pension benefits with years since beginning to receive the benefits. Specifically, the regression includes binary variables for the years during which an individual has been receiving pension benefits, where benefits have been received (1) for less than 1 year, (2) for 1 to 2 years, (3) for 3 to 5 years, and (4) for 6 years or more. (The reference category is having not yet begun to receive pension benefits.) Table 2, Panel A reports the relative risk ratios from the multinomial logit regression for the sample of Japanese men who had salaried jobs at age 54 (left panel) and for those who were self-employed at age 54 (right panel). ${ }^{14}$ Table 2, Panel B reports the results for U.S. men for whites (left panel) and blacks (right panel).

Japanese men who had salaried jobs at age 54 gradually move from full-time employment to part-time employment or retirement once they begin to receive pension benefits. Compared with the years before they receive any pension benefits, these men are 4.816 times more likely to retire during the first year of receiving benefits than to work full-time, and they are 3.894 times more likely to work part-time during that first year than to work full-time. There is an uptrend in the estimated relative risk ratios as the number of years since the start of pension benefits increases. Compared with the years before they began to receive their pension benefits, those who have been receiving benefits for 6 years or longer are 13.64 times more likely to be retired than to be working full-time, and 9.373 times more likely to be working part-time than working full-time. That is, those who had salaried jobs at age 54 claim pension benefits first and change their employment status later rather than simultaneously deciding to receive their pensions and to retire or work parttime.

Meanwhile, for Japanese men who were self-employed at age 54, the estimates are all insignificant, and the estimates of the binary variables for the number of years since the initial claim of pension benefits are close to one, up until 5 years after the initial claim of pension benefits.

\footnotetext{
${ }^{14}$ The estimation results for the other variables are close to those in Table 1 and are not reported to conserve space.
} 
For men who began receiving benefits 6 years earlier or longer, the estimates of relative risk increase to only 2.603 for retirement and 1.738 for part-time employment (these estimates are insignificant). Thus, those who are self-employed at age 54 continue to work in the same manner as before, even after they begin to receive pension benefits.

For comparison, we conducted the same multinomial logit estimation using the HRS sample. Compared with the years before they begin to receive Social Security, during the first year of receiving Social Security, U.S. white men are 3.321 times more likely to be retired than to be working full-time, and the estimates for retirement relative to full-time status remain at roughly this level until 5 years have passed since they began receiving Social Security. The estimate increases to 8.344 for those who have been receiving Social Security for 6 years or longer. In contrast, however, the estimated relative risk of working part-time compared with working fulltime is approximately 3 times greater throughout the years after a man begins to receive Social Security. That is, when white men begin to receive Social Security, they often retire altogether or work part-time and maintain that status. However, after 6 or more years have elapsed since they first received Social Security, they are more likely to retire. This employment pattern is different from that in Japan; in particular, (1) Japanese men who had salaried jobs at age 54 move only gradually from full-time status to part-time status or retirement, and (2) Japanese men who were self-employed at age 54 continue to work full-time even after they begin receiving pension benefits.

Compared with the years before they begin to receive Social Security, during the first year of receiving Social Security, U.S. black men are 4.204 times more likely to be retired than to work full-time. These estimates regarding the likelihood of retirement compared to full-time status steadily increase, so that in the periods of $1-2$ years, 3-5 years, and 6 or more years after Social Security benefits start, these men are 3.173 time, 4.536 times, and 8.190 times, respectively, more likely to be retired than to be working full-time. When part-time employment is compared with full-time employment, during the first year of receiving benefits U.S. black men are 3.927 times 
more likely to work part-time than to work full-time, and the estimated relative risk increases slightly to 4.866 times after 6 years or more since the initial Social Security claim. These patterns for blacks are also distinctly different from those of Japanese men-for whom the movement from full-time employment to part-time employment or retirement is more gradual or not observed.

\section{Changes in working hours before and after the initial pension benefits claim}

To capture in more detail the evolution of working hours before and after receipt of the first pension benefits, we examine how working hours - in particular, hours per week and weeks per year - change before and after the initial receipt of pension benefits. To do this, we regress hours of work on the same sets of covariates that were used in Table 2. The regression analysis on hours of work will be restricted to those with positive hours.

Table 3, Panel A reports the estimation results for hours per week in the left panel and weeks per year in the right panel separately for Japanese men who had salaried jobs at age 54 and for those who were self-employed at age 54. Table 3, Panel B reports those results for the U.S. men separately for whites and for blacks. For Japanese men who had salaried jobs at age 54, hours per week decrease by 5.5 hours and weeks per year by 2.3 weeks, once they begin to receive pension benefits, which corresponds to a reduction of approximately $340[\approx 35 \times 50-(35-5.5) \times(50-2.3)]$ hours for one year as a whole if we assume that the men work 35 hours per week and 50 weeks per year before claiming pension benefits. For those who began receiving benefits six years ago or longer, their hours per week decrease by 10.9 hours, although their weeks per year decrease by only 1.0 week. That is, the number of weeks per year gradually returns to the level before they began claiming benefits, perhaps because only those with high labor force attachment continue to work after 6 years or more after beginning to receive pension benefits. These decreases correspond to a reduction of approximately 420 hours $[\approx 35 \times 50-(35-10.9) \times(50-1.0)]$ for one year. In sum, those who had salaried jobs at age 54 reduce both hours per week and weeks per year just after they begin to receive pension benefits, and the total number of annual hours continues to decline 
subsequently.

In contrast, for Japanese men who were self-employed at age 54, the years since they began to receive pension benefits are not associated with hours per week or weeks per year; the estimates are all small and insignificant. This confirms that for this group, adjusting their work hours is not related to their receipt of pension benefits.

The results for white U.S. men show that during the first year of receiving Social Security, the hours worked per week decline by 6.1 and weeks worked per year decline by 1.8 , corresponding to a reduction of approximately $360[\approx 35 \times 50-(35-6.1) \times(50-1.8)]$ hours per year. These declines in hours per week and weeks per year are gradual; beginning 6 years or more after they start to receive Social Security, their hours worked per week decline by 10.3 and weeks worked per year by 5.7 , corresponding to a reduction of approximately $660[\approx 35 \times 50-(35-10.3) \times(50-$ 5.7)] hours per year. Therefore, for the white men who work after they begin to receive Social Security, their hours decline quite significantly, much more than those for the Japanese men who had salaried jobs at age 54. As shown in Table 2, U.S. white men are more likely than Japanese men to decide to start their retirement and their receipt of Social Security benefits simultaneously. However, those men who remain in the labor force after they begin to receive Social Security are able to reduce their working hours drastically (compared to their working hours before they began to receive Social Security), from a reduction of 360 hours during the first year of receiving Social Security to a reduction of 660 hours 6 years or longer after the Social Security benefits began.

This result is in contrast to that for Japanese men, who reduce their worktime by 340 hours per year during the first year that they receive public pension benefits, and by 420 hours per year 6 or more years after they started receiving benefits, compared with their hours worked before they began to receive public pension benefits. Rather than completely leaving the labor force, as Japanese men of pensionable age who had salaried jobs at age 54 do, U.S. white men of pensionable age are able to continue working and reduce their hours substantially, suggesting that the elderly in the U.S. are offered more flexibility in their work hours. 
For black U.S. men, during the first year of receiving Social Security, their hours worked per week decline by 5.1 and weeks worked per year decline by 3.9, corresponding to a reduction of approximately $370[\approx 35 \times 50-(35-5.1) \times(50-3.9)]$ hours per year. For those who began receiving Social Security 6 or more years earlier, the hours worked per week decline by 8.7 and weeks worked per year by 5.2 , corresponding to a reduction of approximately $570[\approx 35 \times 50-(35-$ $8.7) \times(50-5.2)]$ hours per year. For black men, hours worked per week decline gradually after they start receiving Social Security, but their weeks worked per year decrease immediately after they begin to receive Social Security and therefore remain at roughly the same level. After they begin to receive Social Security, their hours worked decline, but not as dramatically as those for white men; however, the reduction in working hours for black men is greater than that for Japanese men who had salaried jobs at age 54 .

\section{Changes in hours constraints before and after initial claims of pension benefits}

To capture a job's hours constraints, we construct the binary variables of overemployment and underemployment based on the JSTAR and HRS responses, following Altonji and Paxson (1988, 1992), Altonji and Usui (2007), and Usui (2009, 2015). Specifically, we allocate one to the overemployment variable if the respondent answered "No" to "(Not counting overtime hours,) could you reduce the number of paid hours in your regular work schedule?" and "Yes" to "Would you like to do so even if your earnings were reduced in the same proportion?" and zero otherwise. We also allocate one to the underemployment variable if the respondent answered "No" to "Could you increase the number of paid hours in your regular work schedule?" and "Yes" to "Would you like to do so if your earnings were increased in the same proportion?" and zero otherwise. Because these questions were not included in the JSTAR until 2009 (only for Baseline Sample 2) and 2011, the sample size is substantially smaller. ${ }^{15}$

\footnotetext{
15 The questions on hours constraints are adopted from the HRS. Although the HRS did not ask these questions of self-employed workers, the JSTAR asked them of all workers.
} 
Table 4, Panel A reports the proportions of Japanese men who report being overemployed and underemployed before and after they began to receive pension benefits, and Panel B reports these proportions for U.S. men. For Japanese men who had salaried jobs at age 54, 6.5 percent of workers report underemployment before they began to receive pension benefits, and this percentage increases to 11.3 percent for the year these workers began to receive pension benefits. The percentage remains steady at this level, and 11.6 percent of those who have received pension benefits for 6 years or more report underemployment. However, for those who had salaried jobs at age 54, there is no clear difference in the percentages of overemployment before pension benefits begin and in the first 2 years thereafter. Meanwhile, for those who were self-employed at age 54, 5.1 percent of workers report overemployment before they began to receive pension benefits, and the percentage increases to 14.5 percent for the year they began to receive benefits. For those who were self-employed at age 54, there is no clear difference in the percentages concerning underemployment before and immediately after they begin to receive pension benefits. Therefore, the summary statistics suggest that after they begin to receive public pension benefits, men who had salaried jobs at age 54 are more likely to report underemployment, and those who were self-employed at age 54 are more likely to report overemployment.

In contrast, for U.S. men, the overemployment and underemployment indicators are higher before they begin to receive Social Security than afterward, by between approximately 2 percent and 6 percent. That is, after they begin to receive Social Security, U.S. men are less likely to report either overemployment or underemployment, indicating that they are more satisfied with their working hours after they begin to receive Social Security.

Next, we examine this issue by estimating probit models of overemployment and underemployment, using the same sets of covariates as in Tables 2 and 3. Table 5, Panel A reports the marginal effects on the means for the probit models with overemployment as the outcome in the left panel, and underemployment as the outcome in the right panel, separately for Japanese men who had salaried jobs at age 54 and for those who were self-employed at age 54. Table 5, 
Panel B reports the results for U.S. men separately for whites and for blacks.

In the overemployment model, for the Japanese men who had salaried jobs at age 54, the estimated marginal effects on the number of years since they began to receive pension benefits are all negative, although the findings were significantly negative only when 6 years or more had elapsed after beginning to receive pension benefits. Meanwhile, for those who were self-employed at age 54, the estimated marginal effects on the number of years since these men began to receive pension benefits are significantly positive during the first 2 years after they start receiving pension benefits. Consequently, the opposite results are obtained for the underemployment model. Specifically, the estimated coefficients on the number of years since the men began to receive pension benefits are all positive for those who had salaried jobs at age 54, and significantly positive for these men during the first year of receiving benefits; in contrast, the estimates are all negative for those who were self-employed at age 54, although the coefficients are insignificant.

Although many estimates are not significant, we nevertheless find support for the prediction that men who had salaried jobs at age 54 are more likely to report underemployment after they begin to receive pension benefits, whereas those who were self-employed at age 54 are more likely to report overemployment after they begin to receive benefits.

For U.S. white men, in the overemployment model, the estimated marginal effects on the number of years since beginning to receive Social Security are significantly negative except for during the first year after beginning to receive benefits. In the underemployment model, the estimated marginal effects on the number of years since beginning to receive Social Security are also often negative, although they are insignificant. Similarly, U.S. black men are less likely to report overemployment; the marginal effects of overemployment take negative values (although insignificantly) for all the years after they begin to receive Social Security. The marginal effects for the underemployment model are also significantly negative until 5 years after the men began to receive Social Security.

Men in the U.S. are less likely than their Japanese men to report being overemployed or 
underemployed after they begin to receive Social Security; they are therefore more likely to be satisfied with their work hours than they were before they began to receive benefits. However, Japanese men are more likely than U.S. men to be either overemployed or underemployed after they begin to receive pension benefits.

\section{Conclusion}

This paper is one of the first attempts in Japan to examine how men over age 60 change their employment status and working hours after they claim public pension benefits. In particular, no prior empirical studies have explicitly presented the differences in working behaviors between Japanese men who had salaried jobs in their 50s and those who were self-employed in their 50s. For this study, we used the JSTAR, and we also made a comparison with the U.S. using the HRS.

We found remarkable differences in work and retirement behaviors between Japanese men who had salaried jobs at age 54 and those who were self-employed at that age. Those who had salaried jobs at age 54, who correspond largely to EPI recipients, exhibit a clear shift from fulltime status to part-time status or retirement once they begin to receive pension benefits. For those who remain in the labor force after they begin to receive pension benefits, the more years that have passed after their initial benefit claims, the more these men reduce their hours worked per week without, however, making a significant reduction in weeks worked per year. In contrast, for those who were self-employed at age 54, who typically belong to the NPI group, there is no significant change in employment status (whether full-time employment, part-time employment, or retirement) or working hours (hours per week and weeks per year) after they begin to receive pension benefits. This result is in clear contrast to the U.S., where we find an abrupt change in employment status and working hours immediately after Social Security benefits begin.

Using a series of questions on hours constraints, we find that those who had a salaried job at age 54 tend to reduce their working hours once they begin receiving pension benefits, and tend to be underemployed. This finding suggests that they have not voluntarily adjusted their working 
hours downward, which presumably reflects their limited job opportunities after the mandatory retirement age. In contrast, those who were self-employed at age 54 tend to be overemployed. This finding may reflect (i) the limited scope of arrangements in work conditions, especially when they are engaged in family or small-sized businesses, as well as (ii) the less generous amount of NPI benefits, when compared with EPI benefits.

In an intertemporal model of optimizing individuals' behaviors, individuals are assumed to choose their pensionable ages and labor hours to maximize their lifetime utility. Under this model, individuals optimally choose the number of hours worked, and thus, they are neither overemployed nor underemployed after they begin to receive pension benefits compared with the time period before that. The model is likely to be applicable to the U.S. case because, after U.S. workers begin to receive Social Security, they report neither overemployment nor underemployment compared with the time period before receiving benefits. As we have seen, however, Japanese men who had salaried jobs at age 54 tend to report underemployment, while those who were self-employed at age 54 tend to report overemployment after they begin to receive pension benefits. Therefore, there appear to be factors that distort individuals' intertemporal allocations of work hours in Japan. One such factor is likely to be insufficient pension benefits for those who were self-employed throughout their work lives, given that these individuals are eligible only for the flat-rate portion of the pension and may therefore desire additional income support. In contrast, few employment opportunities exist after the mandatory retirement age of the early 60 s for those who had salaried jobs in their 50s. Policy measures to provide people who were employed in their 50s with more work opportunities — specifically, allowing them to work on a full-time basis, as well as offering more flexible work-would better utilize their potential work capacity. Future research is needed to more clearly identify the factors that cause this distortion in individuals' optimal intertemporal allocations of work hours in Japan. 


\section{References}

Altonji, Joseph G. and Christina H. Paxson (1988). "Labor Supply Preferences, Hours Constraints, and Hours-Wage Trade-offs.” Journal of Labor Economics, vol. 6, no. 2, pp. 254-76.

Altonji, Joseph G. and Christina H. Paxson (1992). "Labor Supply, Hours Constraints, and Job Mobility.” Journal of Human Resources, vol. 27, no. 2, pp. 256-78.

Altonji, Joseph G. and Emiko Usui (2007). “Work Hours, Wages, and Vacation Leave.” Industrial and Labor Relations Review, vol. 60, no. 3, pp. 408-28.

Clark, Robert and Naohiro Ogawa (1997) "Transitions from Career Jobs to Retirement in Japan" Industrial Relations, vol. 36, no. 2, pp. 255-270.

Cutler, David, Ellen Meara, and Seth Richards-Shubik (2012). "Health and Work Capacity of Older Adults: Estimates and Implications for Social Security Policy.” mimeo.

Gruber, Jonathan and David A. Wise (1999). Social Security Programs Around the World. Chicago and London: University of Chicago Press.

Ichimura, Hidekiko, Hideki Hashimoto, and Satoshi Shimizutani (2009). "Japanese Study of Aging and Retirement: First Results.” RIETI Discussion Paper Series 09-E-047. Tokyo, Japan: The Research Institute of Economy, Trade and Industry.

Kahn, Shulamit B. and Kevin Lang (1991). "The Effects of Hours Constraints on Labor Supply Estimates." Review of Economics and Statistics, vol. 73, no. 4, pp. 605-11.

Kahn, Shulamit B. and Kevin Lang (1995). "The Causes of Hours Constraints: Evidence from Canada." Canadian Journal of Economics, vol. 28, no. 4a, pp. 914-28.

Lang, Kevin and Shulamit B. Kahn (2001). "Hours Constraints." in Garnett Picot and Ging Wong, eds., Working Time in Comparative Perspective, vol. I, Kalamazoo, MI: Upjohn Institute, pp. 261-90.

McGarry, Kathleen (2004). "Health and Retirement: Do Changes in Health Affect Retirement Expectations?" Journal of Human Resources, vol. 39, no. 4, pp. 624-48.

McGarry, Kathleen (2008). “How Do Health Shocks Influence Retirement Decisions?” Review of 
Economics of the Household, vol. 7, no. 3, pp. 307-321.

Ministry of Health, Labour and Welfare (2007). Annual Report on Employees and National Pension Insurances. Tokyo, Japan: Ministry of Health, Labour and Welfare.

OECD (2014). OECD Factbook 2014: Economic, Environmental and Social Statistics, OECD Publishing. http://dx.doi.org/10.1787/factbook-2014-en

Okumura, Tsunao and Emiko Usui (2014). "The Effect of Pension Reform on Pension-Benefit Expectations and Savings Decisions in Japan.” Applied Economics. vol. 46, no. 14, pp. $1677-691$.

Oshio, Takashi, Akiko Sato Oishi and Satoshi Shimizutani (2011). "Social Security Reforms and Labor Force Participation of the Elderly in Japan.” Japanese Economic Review, vol. 62, no. 2, pp. $248-71$.

Shimizutani, Satoshi and Takashi Oshio (2010). "New Evidence on the Initial Transition from Career Job to Retirement in Japan.” Industrial Relations, vol. 49. no. 2, pp. 248-74.

Usui, Emiko (2009). "Wages, Non-Wage Characteristics, and Predominantly Male Jobs.” Labour Economics, vol. 16, no. 1, pp. 52-63.

Usui, Emiko (2015). “Occupational Gender Segregation in an Equilibrium Search Model.” IZA Journal of Labor Economics, vol. 4, no. 13, pp. 1-14.

Usui, Emiko, Satoshi Shimizunani, and Takashi Oshio (2015). "Health Capacity to Work at Older Ages: Evidence from Japan.” Institute of Economic Research, Hitotsubashi University.

Wise, David A. ed. (2012). Social Security Programs and Retirement around the World: Historical Trends in Mortality and Health, Employment, and Disability Insurance Participation and Reforms, Chicago: University of Chicago Press. 
Figure 1. Distribution of employment status by age, JSTAR and HRS.

(A) Japanese men who had salaried jobs at age 54

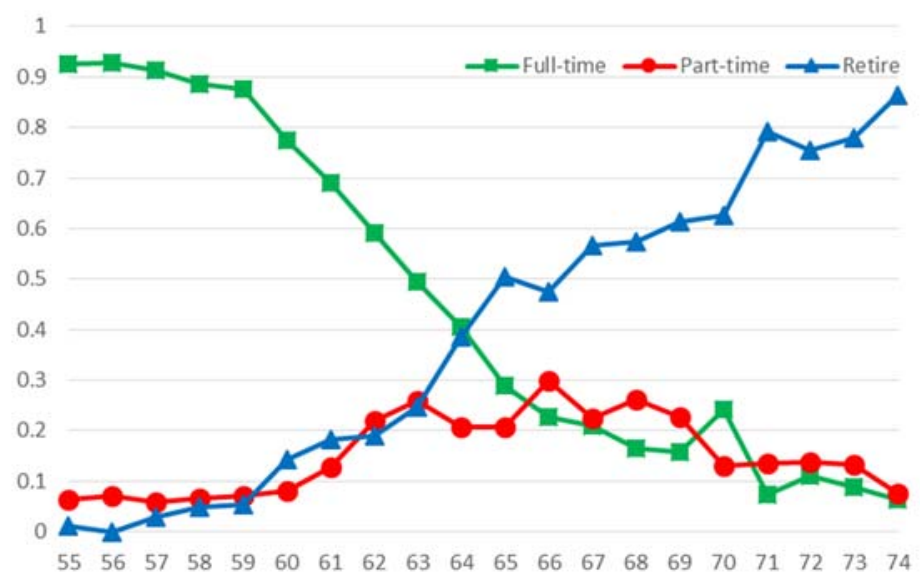

(B) Japanese men who were self-employed at age 54

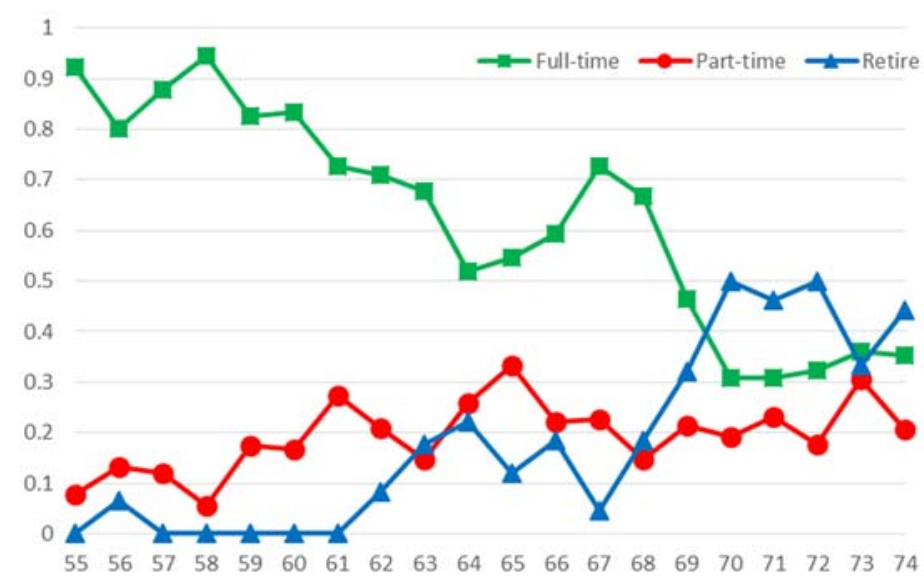

(C) Men in the United States

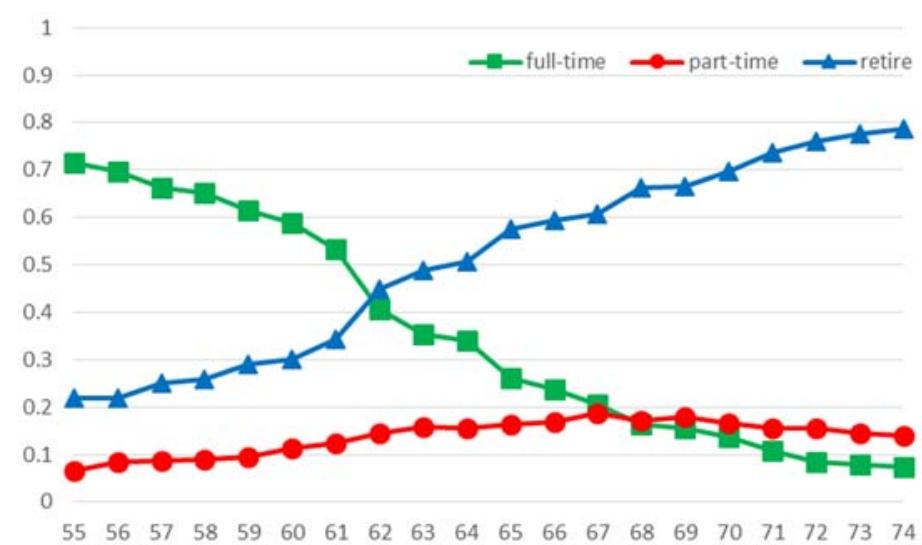


Table 1. Multinomial logit estimates of employment status: Men 60-74, JSTAR.

\begin{tabular}{|c|c|c|c|c|c|c|c|c|c|c|c|c|}
\hline \multirow[b]{3}{*}{ Variable } & \multicolumn{6}{|c|}{ Salaried at age 54} & \multicolumn{6}{|c|}{ Self-employed at age 54} \\
\hline & \multicolumn{3}{|c|}{ Retired } & \multicolumn{3}{|c|}{ Part-time } & \multicolumn{3}{|c|}{ Retired } & \multicolumn{3}{|c|}{ Part-time } \\
\hline & RRR & SE & & RRR & SE & & RRR & SE & & RRR & SE & \\
\hline Self-assessed health: very good & 1.443 & 0.310 & * & 1.216 & 0.269 & & 1.238 & 0.509 & & 1.268 & 0.462 & \\
\hline Self-assessed health: good & 1.212 & 0.233 & & 0.988 & 0.206 & & 1.684 & 0.646 & & 2.426 & 0.851 & ** \\
\hline Self-assessed health: fair or poor & 1.931 & 0.518 & ** & 0.933 & 0.294 & & 2.525 & 1.206 & * & 3.859 & 1.762 & *** \\
\hline Physical functional limitation: 1 & 0.984 & 0.280 & & 0.554 & 0.214 & & 1.825 & 0.897 & & 0.631 & 0.353 & \\
\hline Physical functional limitation: $2+$ & 2.633 & 0.736 & $\star \star \star ~$ & 0.661 & 0.321 & & 2.651 & 1.220 & $\star \star$ & 1.338 & 0.608 & \\
\hline Any IADL limitations & 1.298 & 0.428 & & 0.623 & 0.343 & & 5.879 & 3.869 & $\star \star \star$ & 0.691 & 0.743 & \\
\hline CES-D & 1.028 & 0.058 & & 0.979 & 0.058 & & 1.105 & 0.085 & & 0.962 & 0.079 & \\
\hline Heart disease & 0.997 & 0.245 & & 1.120 & 0.299 & & 1.323 & 0.489 & & 1.012 & 0.430 & \\
\hline Lung disease & 4.187 & 2.521 & *夫 & 4.227 & 2.767 & ** & 1.228 & 1.011 & & 1.929 & 2.065 & \\
\hline Stroke & 1.814 & 0.700 & & 0.333 & 0.276 & & 6.264 & 4.515 & ** & 5.653 & 4.368 & ** \\
\hline Cancer & 0.802 & 0.254 & & 1.066 & 0.433 & & 0.263 & 0.191 & * & 0.506 & 0.331 & \\
\hline Hypertension & 1.335 & 0.228 & * & 1.987 & 0.365 & $\star \star \star$ & 1.391 & 0.415 & & 1.331 & 0.394 & \\
\hline Arthritis & 0.809 & 0.330 & & 0.374 & 0.246 & & 1.334 & 0.959 & & 3.812 & 2.418 & ** \\
\hline Diabetes & 1.231 & 0.271 & & 1.105 & 0.270 & & 0.804 & 0.333 & & 0.629 & 0.224 & \\
\hline Underweight & 0.942 & 0.459 & & 3.141 & 1.772 & ** & 1.167 & 1.139 & & 0.304 & 0.302 & \\
\hline Overweight & 0.721 & 0.131 & * & 0.808 & 0.152 & & 1.530 & 0.490 & & 0.802 & 0.233 & \\
\hline Obese & 1.325 & 0.838 & & 0.568 & 0.296 & & 0.814 & 0.694 & & 2.669 & 2.146 & \\
\hline Former smoker & 1.168 & 0.245 & & 1.148 & 0.259 & & 0.927 & 0.335 & & 1.090 & 0.388 & \\
\hline Current smoker & 0.796 & 0.170 & & 0.837 & 0.201 & & 0.519 & 0.236 & & 1.159 & 0.455 & \\
\hline Below high school & 0.793 & 0.165 & & 0.925 & 0.204 & & 0.907 & 0.313 & & 0.881 & 0.274 & \\
\hline Some college & 0.740 & 0.281 & & 0.509 & 0.229 & & 0.360 & 0.261 & & 1.036 & 0.511 & \\
\hline College & 0.820 & 0.183 & & 0.613 & 0.146 & ** & 0.419 & 0.243 & & 0.944 & 0.387 & \\
\hline Married & 0.500 & 0.148 & ** & 1.070 & 0.325 & & 0.555 & 0.281 & & 1.814 & 1.074 & \\
\hline Blue collar job at age 54 & 1.506 & 0.283 & ** & 1.195 & 0.230 & & 5.751 & 1.903 & $\star \star \star ~$ & 2.250 & 0.789 & ** \\
\hline Low-skilled services at age 54 & 1.990 & 0.673 & ** & 1.621 & 0.660 & & 5.904 & 4.746 & ** & 1.470 & 1.309 & \\
\hline Pension benefits (actual or expected) & 2.315 & 0.186 & $\star \star \star ~$ & 1.804 & 0.148 & 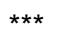 & 1.166 & 0.319 & & 1.264 & 0.278 & \\
\hline Probability of survival until age 85 & 0.774 & 0.116 & * & 0.999 & 0.155 & & 0.453 & 0.131 & $\star \star \star *$ & 1.056 & 0.249 & \\
\hline Log pseudolikelihood & & & -141 & 4.1 & & & & & -46 & & & \\
\hline $\mathrm{N}$ & & & 18 & & & & & & & & & \\
\hline
\end{tabular}

Note: Relative risk ratios are reported. The standard errors are transformed to correspond with the relative risk ratios. The reference group for education is high school education, and that for self-assessed health is excellent health. Regressions include indicators for age, municipality, year, and missing variables. Robust standard errors clustered at the individual level are shown in parentheses. ${ }^{* * *} p<0.01,{ }^{* *} p<0.05,{ }^{*} p<0.1$. 
Table 2. Multinomial logit estimates of employment status: Men 60-74, JSTAR and HRS.

Panel A. JSTAR

\begin{tabular}{|c|c|c|c|c|c|c|c|c|c|c|c|c|}
\hline \multirow{3}{*}{$\begin{array}{l}\text { Years since beginning to } \\
\text { receive pension benefits }\end{array}$} & \multicolumn{6}{|c|}{ Salaried at age 54} & \multicolumn{6}{|c|}{ Self-employed at age 54} \\
\hline & \multicolumn{3}{|c|}{ Retired } & \multicolumn{3}{|c|}{ Part-time } & \multicolumn{3}{|c|}{ Retired } & \multicolumn{3}{|c|}{ Part-time } \\
\hline & RRR & SE & & RRR & SE & & RRR & SE & & RRR & SE & \\
\hline 0 year & 4.816 & 1.455 & $\star \star \star$ & 3.894 & 1.151 & 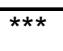 & 1.114 & 0.666 & & 1.852 & 0.822 & \\
\hline 1 to 2 years & 5.556 & 1.973 & $\star \star \star$ & 4.323 & 1.420 & $\star \star \star$ & 0.774 & 0.523 & & 0.646 & 0.334 & \\
\hline 3 to 5 years & 8.453 & 3.069 & $\star \star \star$ & 5.600 & 2.154 & $\star \star \star ~$ & 1.369 & 1.002 & & 1.454 & 0.749 & \\
\hline 6 years and over & 13.64 & 5.673 & $\star \star \star$ & 9.373 & 4.214 & *** & 2.603 & 2.107 & & 1.738 & 1.049 & \\
\hline Log pseudolikelihood & \multicolumn{6}{|c|}{-1472.6} & \multicolumn{6}{|c|}{-474.2} \\
\hline $\mathrm{N}$ & \multicolumn{6}{|c|}{1881} & \multicolumn{6}{|c|}{689} \\
\hline \multicolumn{13}{|c|}{ Panel B. HRS } \\
\hline \multirow{3}{*}{$\begin{array}{l}\text { Years since beginning to } \\
\text { receive Social Security }\end{array}$} & \multicolumn{6}{|c|}{ Whites } & \multicolumn{6}{|c|}{ Blacks } \\
\hline & \multicolumn{3}{|c|}{ Retired } & \multicolumn{3}{|c|}{ Part-time } & \multicolumn{2}{|c|}{ Retired } & & \multicolumn{3}{|c|}{ Part-time } \\
\hline & RRR & SE & & RRR & SE & & RRR & SE & & RRR & SE & \\
\hline 0 year & 3.321 & 0.199 & $\star \star \star \star ~$ & 2.836 & 0.208 & $\star \star \star$ & 4.204 & 0.712 & 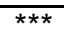 & 3.927 & 0.853 & $\star \star \star$ \\
\hline 1 to 2 years & 3.620 & 0.248 & $\star \star * *$ & 3.296 & 0.276 & $\star \star \star$ & 3.173 & 0.567 & $\star \star * \star$ & 1.973 & 0.478 & $\star \star *$ \\
\hline 3 to 5 years & 3.880 & 0.216 & 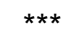 & 3.115 & 0.201 & $\star \star \star$ & 4.536 & 0.624 & $\star \star \star ~$ & 3.839 & 0.705 & $\star \star \star$ \\
\hline 6 years and over & 8.344 & 0.699 & 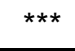 & 3.797 & 0.345 & $\star \star \star$ & 8.190 & 1.423 & $\star \star \star ~$ & 4.866 & 1.071 & $\star \star \star$ \\
\hline Log pseudolikelihood & \multicolumn{6}{|c|}{-23094.5} & \multicolumn{6}{|c|}{-3218.5} \\
\hline $\mathrm{N}$ & \multicolumn{6}{|c|}{28652} & \multicolumn{6}{|c|}{4572} \\
\hline
\end{tabular}

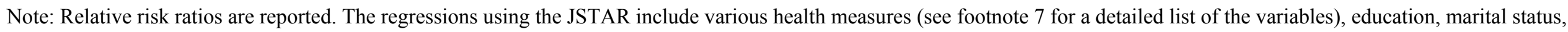

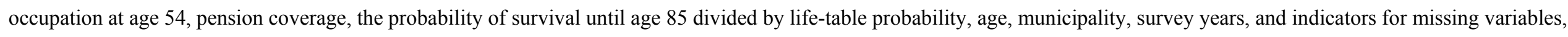
which are also used in the regression analysis in Table 1. The regressions using the HRS include the same variables used in the analysis using the JSTAR. Robust standard errors clustered at the individual level are shown in parentheses. ${ }^{* * *} p<0.01,{ }^{* *} p<0.05,{ }^{*} p<0.1$. 
Table 3. OLS estimates for hours worked: Men 60-74, JSTAR and HRS.

Panel A. JSTAR

\begin{tabular}{|c|c|c|c|c|c|c|c|c|c|c|}
\hline \multirow{3}{*}{$\begin{array}{l}\text { Years since beginning to } \\
\text { receive pension benefits }\end{array}$} & \multicolumn{5}{|c|}{ Hours per Week } & \multicolumn{5}{|c|}{ Weeks per Year } \\
\hline & \multicolumn{3}{|c|}{ Salaried at age 54} & \multicolumn{2}{|c|}{ Self-employed at age 54} & \multicolumn{3}{|c|}{ Salaried at age 54} & \multicolumn{2}{|c|}{ Self-employed at age 54} \\
\hline & Coef. & SE & & Coef. & SE & Coef. & SE & & Coef. & SE \\
\hline 0 year & -5.541 & 1.403 & 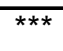 & -0.124 & 2.875 & -2.347 & 0.816 & 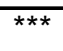 & -1.475 & 1.152 \\
\hline 3 to 5 years & -9.885 & 2.119 & 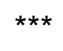 & -1.122 & 3.861 & -1.988 & 0.970 & ** & -1.132 & 1.425 \\
\hline 6 years and over & -10.90 & 2.597 & $\star \star \star ~$ & -3.016 & 4.515 & -0.983 & 1.249 & & -1.985 & 1.378 \\
\hline$\overline{R^{2}}$ & \multicolumn{3}{|c|}{0.195} & \multicolumn{2}{|c|}{0.189} & \multicolumn{3}{|c|}{0.148} & \multicolumn{2}{|c|}{0.153} \\
\hline $\mathrm{N}$ & \multicolumn{3}{|c|}{1026} & \multicolumn{2}{|c|}{522} & \multicolumn{3}{|c|}{1069} & \multicolumn{2}{|c|}{551} \\
\hline
\end{tabular}

Panel B. HRS

\begin{tabular}{|c|c|c|c|c|c|c|c|c|c|c|c|c|}
\hline \multirow{3}{*}{$\begin{array}{l}\text { Years since beginning to } \\
\text { receive Social Security }\end{array}$} & \multicolumn{6}{|c|}{ Hours per Week } & \multicolumn{6}{|c|}{ Weeks per Year } \\
\hline & \multicolumn{3}{|c|}{ Whites } & \multicolumn{3}{|c|}{ Blacks } & \multicolumn{3}{|c|}{ Whites } & \multicolumn{3}{|c|}{ Blacks } \\
\hline & Coef. & SE & & Coef. & SE & & Coef. & SE & & Coef. & SE & \\
\hline 0 year & -6.094 & 0.659 & 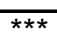 & -5.057 & 1.433 & 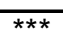 & -1.838 & 0.501 & 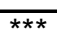 & -3.934 & 1.354 & 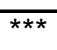 \\
\hline 1 to 2 years & -9.225 & 0.721 & $\star \star \star \star ~$ & -3.998 & 1.917 & $\star \star \star$ & -2.859 & 0.554 & $\star \star \star ~$ & -1.893 & 1.501 & \\
\hline 3 to 5 years & -9.035 & 0.662 & $\star \star \star \star ~$ & -7.511 & 1.488 & $\star \star \star *$ & -3.763 & 0.519 & $\star \star \star \star ~$ & -5.301 & 1.260 & 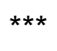 \\
\hline 6 years and over & -10.29 & 1.045 & $\star \star \star *$ & -8.733 & 2.064 & $\star \star \star$ & -5.712 & 0.795 & 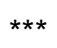 & -5.191 & 1.406 & 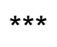 \\
\hline $\mathrm{R}^{2}$ & \multicolumn{3}{|c|}{0.191} & \multicolumn{3}{|c|}{0.196} & \multicolumn{3}{|c|}{0.075} & \multicolumn{3}{|c|}{0.100} \\
\hline $\mathrm{N}$ & \multicolumn{3}{|c|}{8137} & \multicolumn{3}{|c|}{1235} & \multicolumn{3}{|c|}{8090} & \multicolumn{3}{|c|}{1233} \\
\hline
\end{tabular}

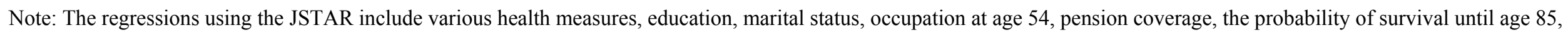

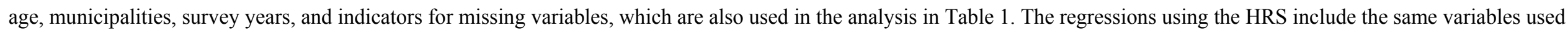

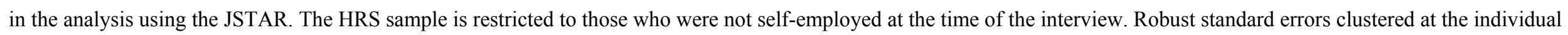
level are shown in parentheses. ${ }^{* * *} p<0.01,{ }^{* *} p<0.05,{ }^{*} p<0.1$. 
Table 4. Summary statistics of overemployment and underemployment: Men 60-74, JSTAR and HRS.

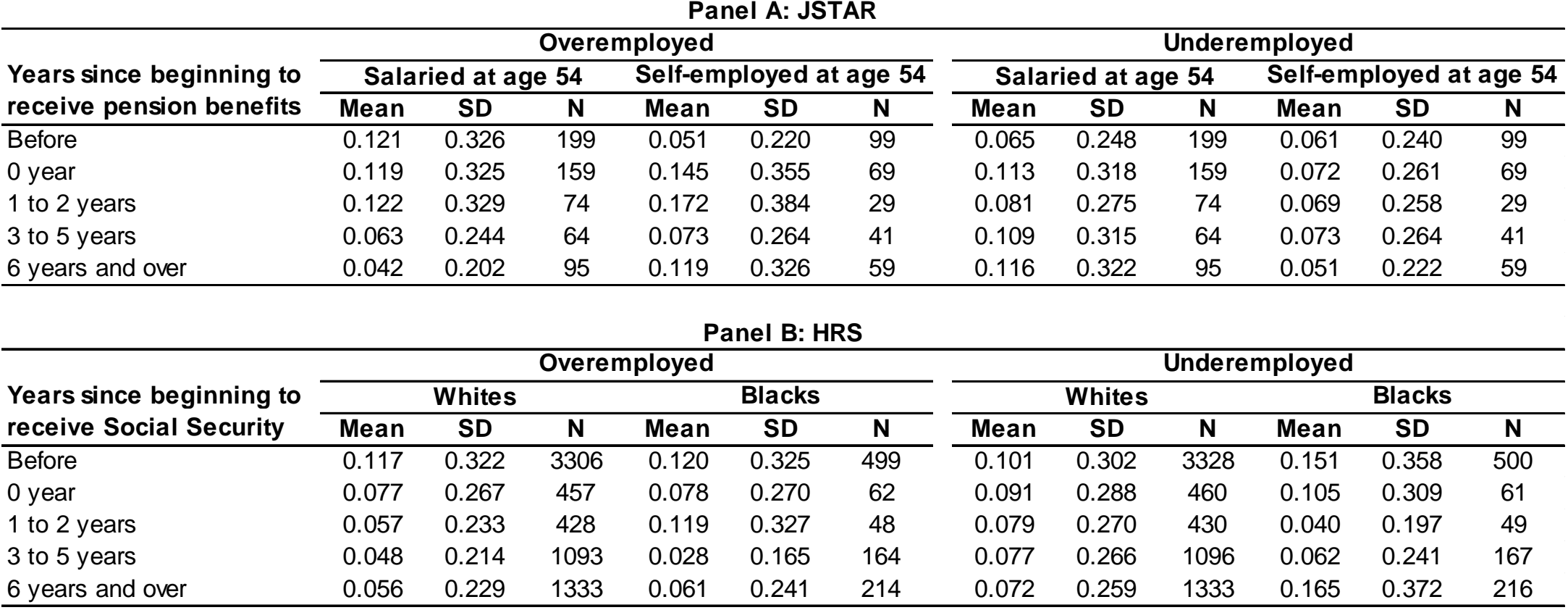

Note: The HRS sample is restricted to those who were not self-employed at the time of the interview. 
Table 5. Probit estimates for hours constraints: Men 60-74, JSTAR and HRS.

(Marginal effects at the mean)

Panel A. JSTAR

\begin{tabular}{|c|c|c|c|c|c|c|c|c|c|c|c|}
\hline \multirow{3}{*}{$\begin{array}{l}\text { Years since beginning to } \\
\text { receive pension benefits }\end{array}$} & \multicolumn{6}{|c|}{ Overemployed } & \multicolumn{5}{|c|}{ Underemployed } \\
\hline & \multicolumn{3}{|c|}{ Salaried at age 54} & \multicolumn{3}{|c|}{ Self-employed at age 54} & \multicolumn{3}{|c|}{ Salaried at age 54} & \multicolumn{2}{|c|}{ Self-employed at age 54} \\
\hline & $\mathrm{dF} / \mathrm{dx}$ & SE & & $\mathrm{dF} / \mathrm{dx}$ & SE & & $d F / d x$ & SE & & $\mathrm{dF} / \mathrm{dx}$ & SE \\
\hline 0 year & -0.012 & 0.023 & & 0.074 & 0.032 & $\star \star$ & 0.061 & 0.028 & ** & -0.022 & 0.020 \\
\hline 3 to 5 years & -0.056 & 0.047 & & 0.048 & 0.044 & & 0.056 & 0.040 & & -0.006 & 0.027 \\
\hline 6 years and over & -0.108 & 0.057 & * & -0.005 & 0.051 & & 0.049 & 0.051 & & -0.002 & 0.036 \\
\hline Log pseudolikelihood & \multicolumn{3}{|c|}{-153.0} & \multicolumn{3}{|c|}{-69.7} & \multicolumn{3}{|c|}{-151.4} & \multicolumn{2}{|c|}{-54.1} \\
\hline $\mathrm{N}$ & \multicolumn{3}{|c|}{579} & \multicolumn{3}{|c|}{290} & \multicolumn{3}{|c|}{579} & \multicolumn{2}{|c|}{290} \\
\hline
\end{tabular}

$\mathrm{N}$

Panel B. HRS

\begin{tabular}{|c|c|c|c|c|c|c|c|c|c|c|c|}
\hline \multirow{3}{*}{$\begin{array}{l}\text { Years since beginning to } \\
\text { receive Social Security }\end{array}$} & \multicolumn{6}{|c|}{ Overemployed } & \multicolumn{5}{|c|}{ Underemployed } \\
\hline & \multicolumn{3}{|c|}{ Whites } & \multicolumn{3}{|c|}{ Blacks } & \multicolumn{2}{|c|}{ Whites } & \multicolumn{3}{|c|}{ Blacks } \\
\hline & $\mathrm{dF} / \mathrm{dx}$ & SE & & $\mathrm{dF} / \mathrm{dx}$ & SE & & $\mathrm{dF} / \mathrm{dx}$ & SE & $\mathrm{dF} / \mathrm{dx}$ & SE & \\
\hline 0 year & 0.0005 & 0.012 & & -0.042 & 0.027 & & -0.004 & 0.013 & -0.100 & 0.035 & 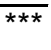 \\
\hline 1 to 2 years & -0.041 & 0.014 & 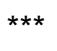 & -0.018 & 0.034 & & -0.021 & 0.016 & -0.140 & 0.046 & $\star \star \star ~$ \\
\hline 3 to 5 years & -0.056 & 0.013 & $\star \star \star$ & -0.058 & 0.034 & * & 0.001 & 0.014 & -0.132 & 0.039 & $\star \star \star ~$ \\
\hline 6 years and over & -0.072 & 0.017 & $\star \star \star$ & -0.051 & 0.036 & & -0.012 & 0.018 & -0.038 & 0.033 & \\
\hline Log pseudolikelihood & \multicolumn{2}{|c|}{-2323.8} & \multicolumn{4}{|c|}{-301.2} & \multicolumn{2}{|c|}{-2458.5} & \multicolumn{3}{|c|}{-413.1} \\
\hline $\mathrm{N}$ & \multicolumn{2}{|c|}{8122} & \multicolumn{4}{|c|}{1146} & \multicolumn{2}{|c|}{8162} & \multicolumn{3}{|c|}{1238} \\
\hline
\end{tabular}

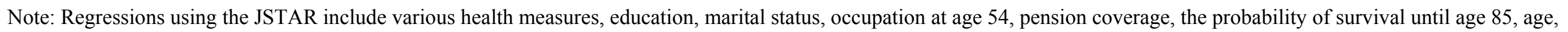

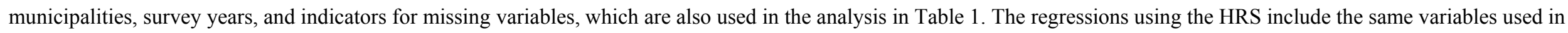

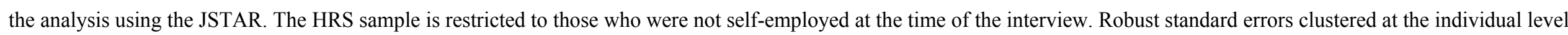
are shown in parentheses. ${ }^{* * *} p<0.01,{ }^{* *} p<0.05,{ }^{*} p<0.1$. 
Appendix Table 1. Summary statistics, JSTAR and HRS.

\begin{tabular}{|c|c|c|c|c|c|c|}
\hline \multirow[b]{3}{*}{ Variable } & \multicolumn{3}{|c|}{ JSTAR } & \multicolumn{3}{|c|}{ HRS } \\
\hline & \multicolumn{3}{|c|}{ Age Group } & \multicolumn{3}{|c|}{ Age Group } \\
\hline & $60-64$ & $65-69$ & $70-74$ & $60-64$ & $65-69$ & $\overline{70-74}$ \\
\hline Retired & 0.195 & 0.477 & 0.670 & 0.408 & 0.617 & 0.751 \\
\hline Part-time worker & 0.179 & 0.227 & 0.154 & 0.137 & 0.174 & 0.153 \\
\hline Full-time worker & 0.625 & 0.296 & 0.176 & 0.454 & 0.209 & 0.096 \\
\hline Self-assessed health: excellent & 0.274 & 0.220 & 0.154 & 0.140 & 0.115 & 0.111 \\
\hline Self-assessed health: very good & 0.246 & 0.258 & 0.258 & 0.323 & 0.318 & 0.277 \\
\hline Self-assessed health: good & 0.349 & 0.363 & 0.348 & 0.306 & 0.318 & 0.336 \\
\hline Self-assessed health: fair & 0.111 & 0.128 & 0.186 & 0.163 & 0.180 & 0.194 \\
\hline Self-assessed health: poor & 0.020 & 0.031 & 0.053 & 0.068 & 0.069 & 0.082 \\
\hline Physical functional limitation: 1 & 0.047 & 0.056 & 0.084 & 0.143 & 0.170 & 0.181 \\
\hline Physical functional limitation: 2+ & 0.052 & 0.101 & 0.160 & 0.185 & 0.202 & 0.241 \\
\hline Any IADL limitations & 0.043 & 0.059 & 0.087 & 0.060 & 0.059 & 0.073 \\
\hline CES-D & 1.042 & 0.957 & 1.164 & 1.159 & 1.068 & 1.072 \\
\hline Heart disease & 0.092 & 0.121 & 0.188 & 0.196 & 0.267 & 0.330 \\
\hline Lung disease & 0.016 & 0.021 & 0.026 & 0.071 & 0.092 & 0.117 \\
\hline Stroke & 0.032 & 0.075 & 0.078 & 0.054 & 0.073 & 0.096 \\
\hline Psychiatric disorder & 0.006 & 0.009 & 0.010 & 0.123 & 0.116 & 0.085 \\
\hline Cancer & 0.043 & 0.053 & 0.057 & 0.088 & 0.135 & 0.181 \\
\hline Hypertension & 0.401 & 0.424 & 0.460 & 0.486 & 0.558 & 0.556 \\
\hline Arthritis & 0.018 & 0.039 & 0.040 & 0.450 & 0.535 & 0.515 \\
\hline Diabetes & 0.143 & 0.206 & 0.197 & 0.178 & 0.219 & 0.213 \\
\hline Underweight & 0.020 & 0.025 & 0.034 & 0.005 & 0.006 & 0.007 \\
\hline Overweight & 0.279 & 0.271 & 0.257 & 0.005 & 0.006 & 0.007 \\
\hline Obese & 0.025 & 0.017 & 0.016 & 0.765 & 0.765 & 0.710 \\
\hline Former smoker & 0.418 & 0.495 & 0.532 & 0.693 & 0.714 & 0.731 \\
\hline Current smoker & 0.357 & 0.273 & 0.190 & 0.194 & 0.157 & 0.117 \\
\hline Below high school & 0.231 & 0.345 & 0.429 & 0.154 & 0.190 & 0.252 \\
\hline High school & 0.450 & 0.429 & 0.392 & 0.323 & 0.341 & 0.334 \\
\hline Some college & 0.065 & 0.042 & 0.047 & 0.230 & 0.203 & 0.174 \\
\hline College & 0.254 & 0.184 & 0.132 & 0.293 & 0.266 & 0.240 \\
\hline Married & 0.891 & 0.916 & 0.913 & 0.762 & 0.768 & 0.771 \\
\hline Currently receiving pension & 0.653 & 0.961 & 0.978 & 0.380 & 0.925 & 0.975 \\
\hline $\mathrm{N}$ & 1269 & 1235 & 1230 & 13309 & 10203 & 11080 \\
\hline
\end{tabular}

